\title{
PENGEMBANGAN RENCANA PELAKSANAAN PEMBELAJARAN (RPP) DAN PENILAIAN DIRI BERBASIS METAKOGNISI UNTUK STATISTIKA ELEMENTER
}

\author{
Isra Nurmai Yenti ${ }^{1}$, Dona Afriyani ${ }^{2}$, Susi Herawati ${ }^{3}$ \\ ${ }^{1} \&{ }^{2}$ Program Studi Tadris Matematika, Jurusan Tabiyah STAIN Batusangkar, ${ }^{3}$ Program Studi \\ Pendidikan Agama Islam Jurusan Tarbiyah STAIN Batusangkar \\ Korespondensi: Jln. Sudirman No.137 Kubu Rajo Lima Kaum Batusangkar, Sumatera Barat \\ e-mail: ${ }^{1}$ nurmaiyenti@yahoo.com, ${ }^{2}$ donaafriyani@gmail.com
}

\begin{abstract}
This research was aimed at developing valid lesson plans and metacognitionbased self evaluation in Statistika Elementer subject. Learning strategies that encouraged students' metacognition were problem-based learning and think pair share. This research employed Research and Development design. There were two main stages in this research: need analysis and prototype design. Need analysis was began with interviewing colleague, analyzing syllabus and lesson plans, analyzing students' characteristics, analyzing lesson plan literature, self evaluation and metacognition. Prototype design referred to need analysis. Three experts recommended that lesson plans and self evaluation were valid both in terms content and construct.
\end{abstract}

Kata kunci: pengembangan, RPP, penilaian diri, metakognisi

\section{PENDAHULUAN}

$\mathrm{P}$ erkembangan ilmu pengetahuan, teknologi, dan sains (Ipteks) sangat pesat terutama di bidang telekomunikasi dan informasi. Sebagai akibat dari kemajuan tersebut, arus informasi datang dari segala penjuru dunia secara cepat, sehingga ilmu pengetahuan dan teknologi dengan cepatnya berkembang. Untuk menghadapi kondisi yang selalu berubah dan kompetitif ini, setiap individu perlu memiliki kemampuan dalam mengases, menyaring dan mengorganisasi informasi, kemampuan untuk dapat berpikir secara kritis, sistematis, logis, kreatif, serta kemampuan untuk dapat bekerjasama secara efektif. Pembentukan serta pengembangan sikap dan cara berpikir seperti ini dapat dilakukan dalam proses pembelajaran matematika, karena matematika memiliki struktur dan keterkaitan antar konsep yang kuat dan jelas, sehingga memungkinkan siapapun yang mempelajarinya terampil berpikir rasional.

Tujuan dari pembelajaran matematika di perguruan tinggi adalah membantu mahasiswa membangun dan menumbuhkembangkan daya matematis. Daya matematis meliputi kemampuan memecahkan masalah, berargumentasi, membuat koneksi, dan merepresentasikan. Kelima kemampuan tersebut dikenal dengan istilah standar proses daya matematis (NCTM, 1999). Berdasarkan hasil penelitian tentang pencapaian tingkat penguasaan matematika, diperoleh informasi bahwa peserta didik Indonesia baru mampu menguasai tahap kognitif level pengetahuan dan data 15 tahun terakhir menunjukkan bahwa Indonesia menduduki posisi ke-42 untuk pencapaian level aplikasi, analisis, evaluasi dan kreatif. 
Permasalahan tersebut merupakan pekerjaan rumah terberat yang harus diselesaikan oleh semua praktisi pendidikan matematika. Kenyataannya, selama ini semua pihak yang terkait sudah berupaya dalam meningkatkan mutu pembelajaran matematika mulai dari pembenahan kurikulum, peningkatan mutu guru, penyempurnaan buku pelajaran, sampai pada melengkapi sarana dan prasarana pendukung. Munculnya berbagai macam strategi pembelajaran matematika modern, menarik minat para tenaga pengajar untuk menerapkannya dalam pembelajaran matematika. Banyak penelitian yang telah menguji bahwa dengan strategi pembelajaran tersebut peserta didik lebih cepat memahami konsep-konsep matematika dibandingkan dengan menggunakan metode konvensional. Usaha tersebut tidak akan membuahkan hasil maksimal jika peserta didik tidak memiliki kesiapan untuk belajar dan sikap mental sebagai seorang yang belajar.

Sekolah Tinggi Agama Islam Negeri (STAIN) Batusangkar sebagai salah satu institusi pendidikan yang memiliki Program Studi Tadris Matematika, juga memiliki persoalan yang sama. Berdasarkan hasil penelitian sebelumnya, yaitu Penelusuran Perilaku Metakognitif Mahasiswa Tadris Matematika dalam Pemecahan Masalah Matematika (Afriyani, 2010), ditemukan bahwa sebagian besar mahasiswa Tadris Matematika belum memiliki perilaku metakognitif, sehingga tidak memiliki kecakapan berpikir kritis dan kreatif dalam memecahkan masalah. Padahal, kecakapan berpikir kritis dan kreatif merupakan bagian dari visi Program Studi Tadris Matematika.

Fakta yang ditemukan dari penelitian tersebut adalah lebih dari 50\% mahasiswa Tadris Matematika belum mampu merancang, memantau, dan merefleksikan proses belajarnya. Mahasiswa belum terbiasa membekali dirinya dengan membaca terlebih dahulu konsep yang akan ia terima di perkuliahan, yaitu dengan cara mencari dan mempelajari buku sumber di perpustakaan, mengakses internet, dan membentuk komunitas belajar dengan cara mendiskusikan konsep yang akan dan yang sudah mereka pelajari di perkuliahan.

Mahasiswa juga belum mampu mengorganisasikan materi pelajaran dengan cara membuat outlining, mind mapping, dan strategi belajar lainnya. Akibatnya, mahasiswa tidak dapat membuat dan menjaga catatan pikirannya. Terakhir, mahasiswa belum mampu mengevaluasi proses belajar yang sudah dilaluinya, sehingga mereka tidak dapat mengidentifikasi tingkat pencapaian belajarnya.

Berdasarkan karakteristik permasalahan di atas, dapat dikatakan bahwa mahasiswa Tadris Matematika belum memiliki komponen-komponen metakognisi. Padahal berdasarkan hasil penelitian yang dilakukan oleh Flavell (1979) dan Biryukov (2004), menunjukkan bahwa metakognisi memainkan peranan penting dalam keberhasilan belajar mahasiswa. Oleh karena itu, permasalahan di atas harus segera diatasi. Jika tidak, mahasiswa Tadris Matematika akan terjebak pada gaya belajar yang tidak tepat dan perlahan-lahan akan menjadi warisan yang berujung pada terbentuknya budaya belajar yang jelek.

Upaya yang perlu dilakukan untuk mengatasi permasalahan di atas adalah dengan menerapkan strategi perkuliahan yang berorientasi untuk memperkaya, memperdalam, dan memperluas keterampilan mahasiswa dalam memecahkan masalah matematika. Kesuksesan mahasiswa dalam memecahkan masalah tergantung pada kesadarannya tentang apa yang mereka ketahui dan bagaimana dia melakukannya (Suherman, 2004: 104). Mahasiswa perlu disadarkan tentang pengetahuan dan proses berpikir yang mereka miliki. Mahasiswa harus memiliki kesadaran bahwa mereka perlu tahu tentang konsep dasar dalam memecahkan suatu masalah. Akibatnya, dengan kesadaran ini diharapkan mereka mampu menyusun strategi untuk memecahkan masalah yang dihadapi. 
Mahasiswa juga harus memiliki kesadaran untuk mengevaluasi strategi yang dia digunakan ketika memecahkan masalah.

Berdasarkan karakteristik bahwa proses yang dilakukan berupa tindakan untuk menyadarkan kemampuan kognitif mahasiswa, maka proses penyadaran kemampuan kognitif ini merupakan upaya secara metakognisi. Metakognisi tersebut memiliki tiga komponen, yaitu: pengetahuan metakognisi, keterampilan metakognisi dan pengalaman metakognisi. Pengetahuan metakognisi dapat dilihat ketika mahasiswa sadar tentang kemampuan kognitifnya. Keterampilan metakognisi akan dimiliki seseorang jika ia memiliki kesadaran tentang pengetahuan metakognisi. Pengalaman metakognisi akan diperoleh seseorang ketika ia menyadari dan mengontrol strategi kognitif yang dimilikinya.

Berkaitan dengan maksud tersebut di atas, maka perlu dikembangkan suatu Rencana Pelaksanaan Pembelajaran (RPP) dan penilaian diri berbasis metakognisi pada mata kuliah Statistika Elementer. Hal ini didasari oleh mata kuliah Statistika Elementer merupakan pengantar untuk statistika dalam matematika dan karakteristik materinya bersifat open ended yang membutuhkan proses berpikir logis, kritis dan kreatif. Untuk itu, mahasiswa perlu menyadari dan mengontrol kemampuan kognitifnya, sehingga ia tidak dengan mudah melupakan konsep dasar statistika dan mahasiswa mampu memecahkan permasalahan.

\section{RENCANA PELAKSANAAN PEM- BELAJARAN (RPP)}

Rencana pelaksanaan pembelajaran merupakan panduan guru atau dosen dalam kegiatan pembelajaran. Rencana pelaksanaan pembelajaran disusun untuk setiap kali pertemuan. Kegiatan pembelajaran dikembangkan dari tujuan pembelajaran yang mengacu pada indikator kompetensi. Komponen-komponen pen- ting yang harus ada dalam rencana pelaksanaan pembelajaran meliputi; Standar Kompetensi (SK), Kompetensi Dasar (KD), indikator kompetensi, deskripsi materi, model dan metode pembelajaran, skenario pembelajaran, dan penilaian.

Standar kompetensi berpedoman pada silabus yang sudah dikembangkan, kemudian dijabarkan dalam bentuk kompetensi dasar. Kompetensi dasar merupakan standar minimal yang harus di capai oleh peserta didik. Seorang guru atau dosen boleh mengembangkan kompetensi dasar disesuaikan dengan kompleksitas materi pelajaran, kompleksitas karakteristik peserta didik, dan waktu yang tersedia. Selanjutnya kompetensi dasar diuraikan kembali ke dalam indikator-indikator kompetensi.

Indikator kompetensi yang bagus memiliki ciri-ciri sebagai berikut; (a) memuat kemampuan dasar yang diukur, (b) memuat kata kerja operasional yang dapat diukur, (c) Berkaitan dengan materi yang diajarkan, (d) dapat dibuat bentuk soalnya (Prajitno, 2003: 10). Agar indikator yang sudah ditetapkan dapat dicapai, maka guru/dosen harus terampil memilih model dan metode pembelajaran.

Pemilihan model dan metode pembelajaran diarahkan untuk memunculkan pembelajaran yang terpadu, sehingga harus disesuaikan dengan karakteristik materi dan peserta didik. Karakter peserta didik yang diharapkan adalah peserta didik yang menyadari bahwa mereka adalah seorang yang sedang belajar untuk mencapai suatu tujuan, sehingga model pembelajaran yang dipilih untuk mendukung upaya penyadaran kognitif yang dimiliki peserta didik (pendekatan matakognisi). Melalui pendekatan metakognisi diharapkan peserta didik memiliki pengetahuan metakognisi, keterampilan metakognisi, dan pengalaman metakognisi.

Langkah-langkah model pembelajaran ini dituangkan dalam skenario pembelajaran. Skenario pembelajaran yang dirancang menggambarkan aktiv- 
itas belajar agar peserta didik menyadari dan penggunakan pengetahuan yang dimilikinya untuk memecahkan masalah, mengetahui dan menggunakan strategistrategi yang dapat digunakan memecahkan masalah, memonitor pengetahuan dan pekerjaan sehingga dapat mendeteksi kesalahan yang diperbuat, mampu memperbaiki kesalahan yang diperbuat dan mengevaluasi kembali pekerjaan. Beberapa model yang digunakan untuk memunculkan aktivitas-aktivitas tersebut adalah model pembelajaran berbasis masalah dan model pembelajaran kooperatif tipe Think Pair Share.

\section{METAKOGNISI}

Metakognisi berasal dari kata "metacognition" dengan prefik "meta" dan kata "kognisi". Meta berasal dari bahasa Yunani yang berarti "setelah", "melebihi", atau "di atas". Secara umum kognisi diartikan sebagai apa yang diketahui serta difikirkan oleh seseorang. Gambaran klasik mengenai kognisi meliputi "Higher Mental Processes" seperti pengetahuan, kesadaran, inteligensi, fikiran, imajinasi, daya cipta, perencanaan, penalaran, penyimpulan, pemecahan masalah, pembuatan konsep, pembuatan klasifikasi-klasifikasi dan kaitan-kaitan, pembuatan simbol-simbol dan mungkin juga fantasi serta mimpi. Metakognisi mengacu kepada kesadaran mahasiswa terhadap kemampuan yang dimilikinya serta kemampuan untuk memahami, mengontrol dan memanipulasi proses-proses kognitif yang mereka miliki.

Konsep metakognisi yang dikemukakan Biryukov (2004) mengacu kepada dugaan pemikiran tentang apa yang seseorang tahu yang disebut "pengetahuan metakognisi", apa yang dapat seseorang kerjakan yang disebut "keterampilan metakognisi", dan apa yang seseorang tahu tentang keterampilan metakognisinya yang disebut "pengalaman metakognisi".

\section{Pengetahuan Metakognisi}

Menurut Robinson dalam (www.damandiri.co.id), pengetahuan metakognisi dapat dilihat ketika mahasiswa sadar tentang kemampuan kognitifnya. Contoh, mahasiswa mengetahui ia mempunyai memori yang kurang baik untuk materi pelajaran tertentu; untuk menilai prestasinya, ia membuat catatan tentang prestasinya. Flavell (1979) menegaskan bahwa pengetahuan metakognisi merupakan pengetahuan yang diperoleh mahasiswa tentang proses-proses kognitif yaitu pengetahuan yang bisa digunakan untuk mengontrol proses-proses kognitif. Ia membagi pengetahuan metakognisi menjadi tiga kategori: pengetahuan tentang variabelvariabel personal, variabel-variabel tugas, dan variabel-variabel strategi.

Pengetahuan tentang variabel-variabel personal berkaitan dengan pengetahuan tentang bagaimana mahasiswa belajar dan memproses informasi serta pengetahuan tentang proses-proses belajar yang dimilikinya. Contoh, seorang mahasiswa sadar bahwa proses belajar lebih produktif jika dilakukan di perpustakaan daripada di rumah. Pengetahuan tentang variabel-variabel tugas melibatkan pengetahuan tentang sifat tugas dan jenis pemrosesan yang harus dilakukan untuk menyelesaikan tugas itu. Contoh, mahasiswa sadar bahwa membaca dan memahami teks ilmu pengetahuan memerlukan lebih banyak waktu daripada membaca dan memahami sebuah novel. Pengetahuan tentang variabel-variabel strategi melibatkan pengetahuan tentang strategi-strategi kognitif dan metakognisi serta pengetahuan kondisional tentang kapan dan dimana strategi-strategi itu digunakan.

\section{Keterampilan Metakognisi}

Menurut teori metakognisi, mahasiswa yang belajar memiliki keterampilan-keterampilan tertentu untuk mengatur dan mengontrol apa yang dipelajarinya. Menurut Woolfolk dalam Uno (2008: 134), keterampilan ini berbeda antara 
satu individu yang satu dengan individu yang lain sesuai dengan kemampuan proses berfikirnya. Ia mengemukakan empat jenis keterampilan metakognisi, yaitu sebagai berikut:

1. Keterampilan pemecahan masalah, yakni keterampilan seseorang mahasiswa dalam menggunakan proses berpikirnya untuk memecahkan masalah melalui pengumpulan fakta, menganalisis informasi, menyusun berbagai alternatif pemecahan, dan memilih pemecahan masalah yang paling efektif.

2. Keterampilan pengambilan keputusan, yakni keterampilan seseorang menggunakan proses berfikirnya untuk memilih sesuatu keputusan yang terbaik dari beberapa pilihan yang ada melalui pengumpulan informasi, dan pengambilan keputusan yang terbaik berdasarkan alasan yang rasional.

3. Keterampilan berfikir kritis, yakni keterampilan seseorang dalam menggunakan proses berfikirnya untuk menganalisis argumen dan memberikan interpretasi berdasarkan persepsi yang sahih melalui logical reasoning, analisis asumsi dan bias dari argument dan interpretasi logis

4. Keterampilan berfikir kreatif, yakni keterampilan seseorang dalam menggunakan proses berfikirnya untuk menghasilkan suatu ide baru, konstruktif, dan baik berdasarkan konsepkonsep, prinsip-prinsip yang rasional, maupun persepsi dan intuisi.

Seseorang akan memiliki keterampilan metakognisi jika ia memiliki kesadaran tentang pengetahuan metakognisi dan strategi-strategi metakognisi yang digunakan dalam menyelesaikan tugas. Strategi metakognisi dimaksud adalah perencanaan diri, pemantauan diri dan evaluasi diri.

\section{Pengalaman Metakognisi}

Menurut Flavel dalam Biryukov (2004: 1), pengalaman metakognisi merupakan sesuatu yang berkenaan dengan apakah seseorang menyadari dan mengontrol strategi kognitif yang dimilikinya. Upaya pengontrolan strategi kognitif yang dimilikinya dinamakan dengan strategi-strategi metakognisi yang meliputi perencanaan diri, pemantauan diri, dan evaluasi diri. Flavel (www.damandiri.or.id) menegaskan bahwa strategi-strategi metakognisi merupakan proses-proses yang berurutan yang digunakan untuk mengontrol aktivitas kognitif dan memastikan bahwa tujuan kognitif telah dicapai. Proses ini terdiri dari perencanaan dan pemantauan aktivitas-aktivitas kognitif serta evaluasi terhadap hasil aktivitas tersebut.

Aktivitas perencanaan seperti menentukan tujuan dan analisis tugas membantu mengaktivasi pengetahuan yang relevan sehingga mempermudah pengorganisasian dan pemahaman materi pelajaran. Aktivitas pemantauan meliputi perhatian seseorang ketika ia membaca, dan membuat pertanyaan atau pengujian diri. Aktivitas ini membantu siswa dalam memahami materi dan mengintegrasikannya dengan pengetahuan awal. Aktivitas pengaturan meliputi penyesuaian dan perbaikan aktivitas-aktivitas kognitif siswa. Aktivitas ini membantu peningkatan prestasi dengan cara mengawasi dan mengoreksi perilakunya pada saat ia menyelesaikan tugas. Contoh, setelah membaca sebuah paragraf di dalam sebuah teks, siswa menanyakan kepada dirinya sendiri tentang konsepkonsep yang didiskusikan di dalam paragraf itu. Tujuan kognitifnya adalah untuk memahami teks itu. Menanyakan kepada dirinya sendiri merupakan strategi-strategi metakognisi. Jika ia menemukan bahwa ia tidak bisa menjawab pertanyaannya sendiri, atau ia tidak dapat memahami materi yang didiskusikan, ia kemudian menentukan apa yang perlu dilakukan untuk memastikan bahwa ia mencapai tujuan kognitif itu. Ia barangkali memutuskan untuk mengulangi atau membaca kembali paragraf itu agar mampu menjawab pertanyaannya sendiri. 


\section{Keyakinan dan Intuisi}

Kenyakinan dan intuisi menyangkut ide-ide matematika apa yang disiapkan untuk menyelesaikan masalah matematika dan bagaimana ide-ide tersebut dapat membentuk jalan/cara untuk menyelesaikan masalah matematika. Kelihatannya, Schoenfeld memberikan keyakinan dan intuisi ini sebagai proses metakognisi dimana sebelum seseorang dapat mengerjakan, ia memiliki keyakinan bahwa masalah dapat diselesaikan, ia juga memiliki intuisi bahwa masalah yang timbul dapat diselesaikan dengan ide-ide tertentu. Dengan memiliki kategori keyakinan dan intuisi ini berarti mahasiswa berusaha untuk memiliki kepercayaan diri bahwa ia dapat menyelesaikan permasalahan itu.

\section{Pengetahuan Mengenai Proses Ber- fikir Seseorang}

Ini berkaitan dengan seberapa akurat seseorang dapat menggambarkan mengenai pemikirannya. Pemecahan masalah yang baik menggunakan apa yang diketahui secara efisien. Pada bagian ini Schoenfeld lebih menekankan pada proses pengorganisasian atau pengelolaan pengetahuan yang berhubungan dengan proses berfikir dalam memecahkan masalah.

\section{Kesadaran Diri atau Pengaturan Diri}

Ini berkaitan dengan keakuratan seseorang dalam menjaga dan mengatur apa yang harus dilakukannya ketika menyelesaikan masalah. Schoenfeld menyarankan bahwa kesadaran diri atau pengaturan diri ini dapat difikirkan menggunakan pendekatan pengelolaan yang meliputi aspek-aspek: mengakses pemahaman terhadap masalah secara keseluruhan, merencanakan strategi penyelesaian, memonitor dan mengontrol cara-cara penyelesaian berjalan, mengalokasikan hasil, memutuskan apa yang harus dilakukan, dan berapa lama masalah tersebut diselesaikan.
Beberapa strategi untuk mengembangkan komponen metakognisi dinyatakan oleh Blakey \& Spence (1990), yaitu: mengidentifikasi apa yang kita ketahui dan apa yang tidak kita ketahui, menceritakan tentang pemikirannya, menjaga catatan pemikiran, merencanakan dan melakukan pengaturan diri, menanyakan proses berfikir, dan evaluasi diri. Huitt (1997) menyatakan bahwa metakognisi meliputi kemampuan untuk bertanya dan menjawab pertanyaan-pertanyan seperti, apa yang saya ketahui tentang topik ini?, apakah saya tahu apa yang perlu saya ketahui?, apakah saya tahu dimana saya mendapatkan informasi yang dibutuhkan?, apa strategi dan taktik yang dapat digunakan?, dan lain sebagainya.

Secara keseluruhan berdasarkan pendapat-pendapat yang diuraikan di atas, dapat dikatakan bahwa dalam proses pembelajaran karakteristik metakognisi lebih dominan pada memonitor kesadaran pengetahuan, strategi, dan proses berfikir diri sendiri melalui pertanyaan-pertanyaan. Pertanyaan-pertanyaan di atas pada hakikatnya adalah pertanyaan yang memandu proses berpikir secara mandiri dan pertanyaan ini dapat muncul dari diri sendiri.

\section{METODE PENELITIAN}

Jenis penelitian yang dipakai adalah pendekatan penelitian pengembangan (development research). Pendekatan penelitian pengembangan digunakan untuk merancang dan mengembangkan RPP dan penilaian diri berbasis metakognisi yang valid. Akker (1994) mengkarakterisasikan penelitian pengembangan berdasarkan dua tujuannya, yaitu: (1) development of prototypical products (curriculum documents and materials), including empirical evidence of their quality, (2) generating methodological directions for the design and evaluation of such products.

Rancangan penelitian ini terdiri dari 2 (dua) langkah, yaitu: melakukan 
analisis muka-belakang (Front-End Analysis) dan tahap prototipe yaitu perancangan RPP dan penilaian diri berbasis metakognisi dan validasi RPP dan penilaian diri. Prosedur penelitian ini dapat digambarkan dalam diagram alur (Gambar 1).

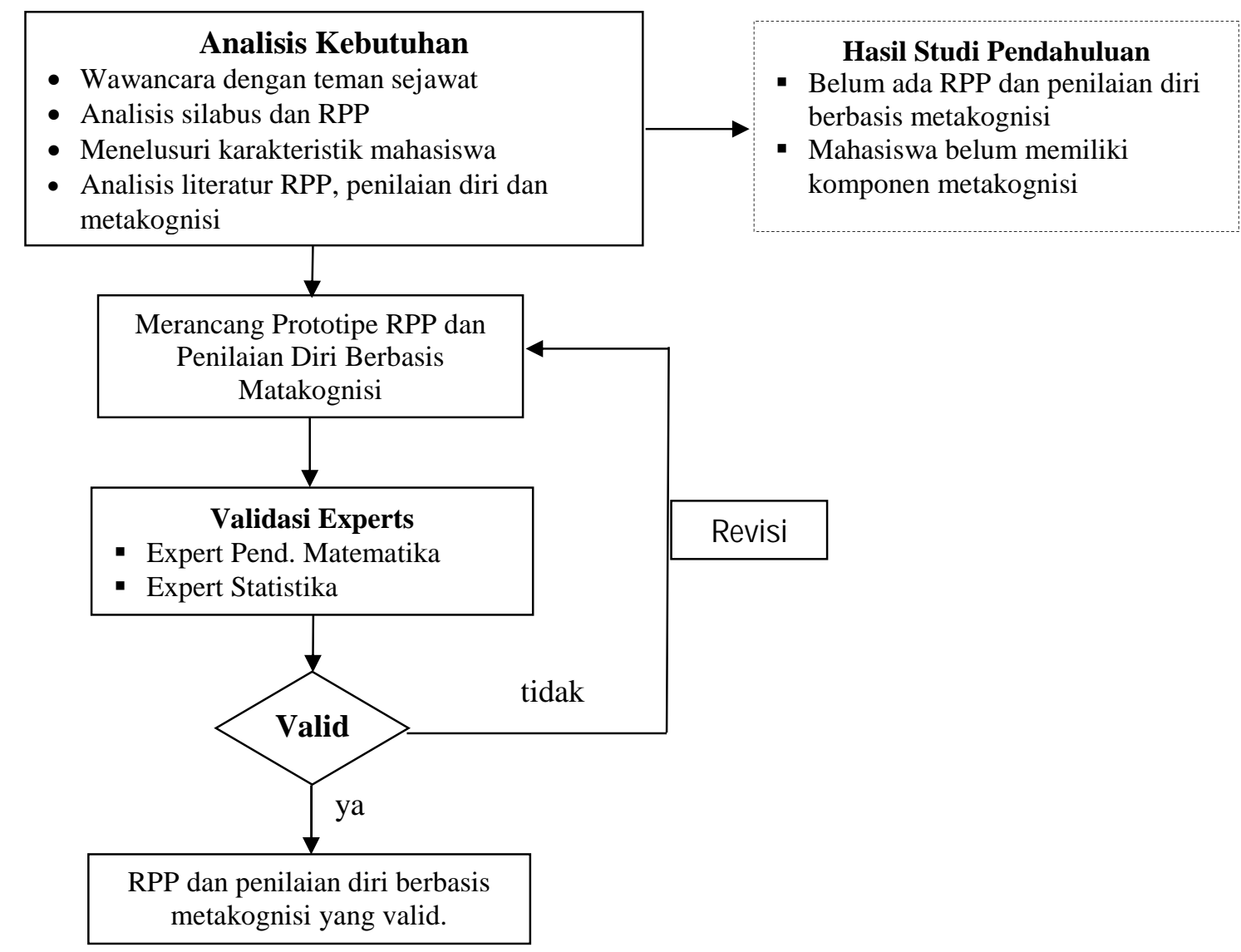

Gambar 1. Prosedur Penelitian

Validasi RPP dan penilaian diri berbasis metakognisi dilihat dari segi isi pada lembar validasi tercantum pada Tabel 2. dan kontruk. Pertanyaan yang diajukan

Tabel 2. Validasi prototipe RPP dan penilaian diri berbasis metakognisi untuk Statistika Elementer

\begin{tabular}{|c|c|c|}
\hline Aspek yang divalidasi & $\begin{array}{c}\text { Metode } \\
\text { Pengumpulan } \\
\text { Data }\end{array}$ & Instrumen \\
\hline $\begin{array}{l}\text { Aspek komponen RPP } \\
\text { - Apakah RPP memuat identitas mata kuliah? } \\
\text { - Apakah RPP memuat Standar Kompetensi (SK)? } \\
\text { - Apakah SK dijabarkan secara tepat ke dalam Kompetensi } \\
\text { Dasar (KD)? } \\
\text { - Apakah RPP menggunakan berbagai macam sumber belajar? } \\
\text { - Apakah materi yang dijabarkan sesuai dengan indikator yang } \\
\text { - hendak dicapai? } \\
\text { Apakah indikator kompetensi yang hendak dicapai sesuai } \\
\text { dengan waktu yang disediakan? }\end{array}$ & \multirow[t]{2}{*}{$\begin{array}{l}\text { Diskusi dengan } \\
\text { pakar pendidikan } \\
\text { matematika dan } \\
\text { statistika }\end{array}$} & \multirow[t]{2}{*}{$\begin{array}{l}\text { Lembar } \\
\text { validasi }\end{array}$} \\
\hline $\begin{array}{l}\text { Aspek Kegiatan Pembelajaran } \\
\text { - Apakah menggunakan model pembelajaran yang sesuai dengan } \\
\text { pendekatan metakognisi? }\end{array}$ & & \\
\hline
\end{tabular}


- Apakah langkah-langkah pelaksanaan pembelajaran disajikan secara jelas?

- Apakah mahasiswa difasilitasi untuk membentuk pengetahuan faktual?

- Apakah kegiatan pembelajaran memberikan kesempatan kepada mahasiswa untuk merumuskan pertanyaan?

- Apakah kegiatan pembelajaran memunculkan keyakinan dalam menyelesaikan masalah?

- Apakah kegiatan pembelajaran memberikan kesempatan kepada mahasiswa untuk menyadari dan mengontrol pengetahuannya?

- Apakah kegiatan pembelajaran memberikan kesempatan kepada mahasiswa membuat kesimpulan, pertimbangan dan keputusan yang benar?

- Apakah kegiatan pembelajaran memberikan kesempatan kepada mahasiswa untuk melakukan penilaian diri?

Aspek Penilaian Diri

- Apakah pernyataan sesuai dengan indikator?

- Apakah kalimat yang digunakan sesuai dengan kaidah Bahasa Indonesia?

- Apakah kalimat yang digunakan komunikatif?

- Apakah pernyataan yang digunakan tidak bias?

\section{HASIL PENELITIAN}

Prototipe RPP dan penilaian diri berbasis metakognisi dirancang berdasarkan analisis muka belakang, meliputi: wawancara dengan teman sejawat, analisis silabus dan RPP, penelusuran karakteristik mahasiswa, serta analisis literatur RPP, penilaian diri dan metakognisi. Hasil yang diperoleh dari analisis muka belakang, selanjutnya dijadikan acuan dalam merancang RPP dan penilaian diri berbasis metakognisi.

Karakteristik RPP yang telah dirancang dan dikembangkan adalah sebagai berikut:

1. Identitas mata kuliah: berisi satuan pendidikan, mata kuliah, semester, dan alokasi waktu.

2. Standar Kompetensi (SK) dan Kompetensi Dasar (KD) diambil dari silabus matakuliah Statistika Elementer.

3. Indikator kompetensi: Indikator ini dikembangkan dari Kompetensi Dasar yang telah ditentukan pada silabus mata kuliah Statistika Elementer.
4. Sumber belajar: berisi sumber yang digunakan sebagai acuan dalam melaksanakan perkuliahan.

5. Deskripsi materi: berisi ringkasan materi yang akan dibahas pada pertemuan tersebut.

6. Model dan metode pembelajaran: berisi nama model dan metode yang akan dilaksanakan pada pembelajaran. Pada setiap pertemuan digunakan model pembelajaran yang berasosiasi dengan pembelajaran dengan pendekatan metakognisi. Penekanan pendekatan metakognisi ini kepada kegiatan-kegiatan metakognisi yang merangsang berkembangnya komponen metakognisi. Sebagai contoh, pada pertemuan I digunakan model pembelajaran berbasis masalah dengan metode pemberian tugas, tanya jawab dan diskusi. Pada pertemuan berikutnya digunakan model pembelajaran kooperatif tipe think pair share.

7. Kegiatan pembelajaran: berisi aktifitas mahasiswa dan dosen selama pembelajaran berlangsung. Pada setiap pertemuan kegiatan pembelajaran 
disesuaikan dengan model dan metode pembelajaran yang digunakan. Aktivitas yang dirancang disetiap model dan metode pembelajaran tersebut merupakan aktivitas-aktivitas metakognitif sehingga mahasiswa terbiasa mengaktifkan, memonitor, mengatur, mengevaluasi, dan merefleksikan pengetahuannya. Sebagai contoh, aktivitas yang dirancang dalam kegiatan inti RPP (Tabel 3) adalah

Tabel 3. Contoh Kegiatan Pembelajaran dengan Model Pembelajaran Berbasis Masalah

\begin{tabular}{|c|c|c|}
\hline Tahap & Kegiatan yang diharapkan dari dosen & $\begin{array}{c}\text { Kegiatan yang } \\
\text { diharapkan dari } \\
\text { mahasiswa }\end{array}$ \\
\hline 1 & 2 & 3 \\
\hline $\begin{array}{l}\text { Pendahuluan } \mathbf{( 1 5} \\
\text { menit) } \\
\text { 1. (Mengori- } \\
\text { entasikan } \\
\text { mahasiswa pada } \\
\text { masalah) }\end{array}$ & $\begin{array}{l}\text { - } \text { Mengucapkan salam. } \\
\text { - Menyampaikan tujuan perkuliahan. } \\
\text { - Memotivasi mahasiswa dengan memberikan } \\
\text { gambaran tentang perlunya konsep dasar } \\
\text { statistika untuk menganalisis data baik secara } \\
\text { deskriptif maupun secara inferensial. }\end{array}$ & $\begin{array}{l}\text { - } \text { Menjawab salam. } \\
\text { - Menyimak perkataan } \\
\text { dosen. } \\
\text { - } \\
\text { Memperhatikan } \\
\text { contoh yang diberikan } \\
\text { dosen. }\end{array}$ \\
\hline \multirow[t]{2}{*}{1} & 2 & 3 \\
\hline & $\begin{array}{l}\text { - Membagi mahasiswa ke dalam beberapa } \\
\text { kelompok yang beranggotakan } 4 \text { orang. Dengan } \\
\text { cara memasangkan mahasiswa sesuai dengan } \\
\text { tingkat kemampuan mereka berdasarkan Indeks } \\
\text { Prestasi semester sebelumnya. } \\
\text { - Mengajukan masalah yang ada dalam buku kerja } \\
\text { dan meminta mahasiswa untuk mempelajari } \\
\text { masalah tersebut }\end{array}$ & $\begin{array}{l}\text { - Segera mempelajari } \\
\text { masalah dalam kelom- } \\
\text { pok }\end{array}$ \\
\hline $\begin{array}{l}\text { Kegiatan inti (115 } \\
\text { menit) } \\
\text { 2. Mengorga- } \\
\text { nisasikan } \\
\text { mahasiswa } \\
\text { untuk belajar } \\
\text { (45 menit) }\end{array}$ & $\begin{array}{l}\text { - Meminta mahasiswa mendiskusikan buku kerja } \\
\text { bab } 1 \text { tentang pendahuluan }\end{array}$ & $\begin{array}{l}\text { - Mahasiswa berdiskusi } \\
\text { dalam kelompok }\end{array}$ \\
\hline $\begin{array}{l}\text { 3. Membimbing } \\
\text { penyelidikan } \\
\text { individual } \\
\text { maupun } \\
\text { kelompok } \\
(\mathbf{2 0} \text { menit) }\end{array}$ & $\begin{array}{l}\text { - Mengajukan pertanyaan-pertanyaan yang } \\
\text { mengarah kepada pemahaman konsep dasar } \\
\text { statistika, misalnya: apa definisi dari statistika, } \\
\text { perbedaan antara data nominal, ordinal, interval, } \\
\text { dan rasio, perbedaan antara populasi dan sampel } \\
\text { disertai contoh, perbedaan parameter dan } \\
\text { statistik beserta contoh. } \\
\text { - Dosen menanggapi jawaban mahasiswa dengan } \\
\text { mengajukan pertanyaan-pertanyaan; "bagaimana } \\
\text { menurut rekan-rekan yang lain tentang jawaban } \\
\text { tersebut?", “Adakah yang memiliki definisi yang } \\
\text { berbeda?" } \\
\text { - Dosen menyadarkan mahasiswa tentang } \\
\text { pengetahuan yang sudah mereka miliki dengan } \\
\text { cara menyebutkan poin-poin yang seharusnya } \\
\text { sudah mereka pahami (“Sampai disini Saudara } \\
\text { seharusnya sudah bisa memahami pengertian } \\
\text { statistika, mengelompokkan data menurut } \\
\text { jenisnya, membedakan populasi dan sampel, } \\
\text { membedakan parameter dan statistik) }\end{array}$ & $\begin{array}{ll}\text { - } & \text { Mahasiswa } \\
\text { mengeluarkan ide dan } \\
\text { pikirannya untuk } \\
\text { menanggapi } \\
\text { pertanyaaan dosen } \\
\text { sehingga tercipta } \\
\text { suasana diskusi yang } \\
\text { produktif } \\
\text { - } \\
\text { Mahasiswa } \\
\text { mendengarkan } \\
\text { penjelasan dosen }\end{array}$ \\
\hline
\end{tabular}




\begin{tabular}{|c|c|c|}
\hline 1 & 2 & 3 \\
\hline & $\begin{array}{l}\text { - Dosen meminta kelompok mendiskusikan } \\
\text { pertanyaan tersebut dan mencari kebenarannya } \\
\text { dalam buku sumber. } \\
\text { - Dosen meminta mahasiswa untuk bertanya pada } \\
\text { diri mereka sendiri yaitu "apakah saya sudah } \\
\text { memahami semua materi yang sudah saya } \\
\text { pelajari?", kemudian dosen meminta mahasiswa } \\
\text { untuk menuliskan materi-materi apa saja yang } \\
\text { sudah dan yang belum ia pahami. } \\
\text { - Dosen meyakinkan mahasiswa bahwa ia telah } \\
\text { memiliki pengetahuan dan dapat memanfaatkan } \\
\text { pengetahuannya untuk memecahkan masalah }\end{array}$ & 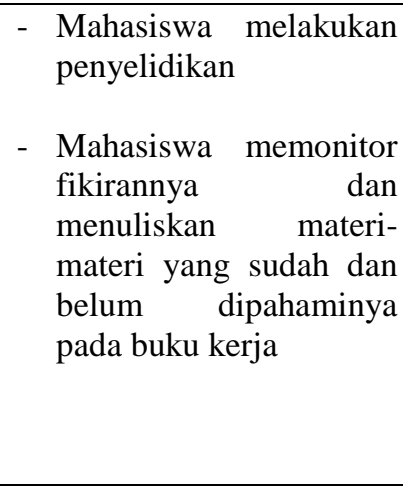 \\
\hline $\begin{array}{l}\text { 4. Mengem- } \\
\text { bangkan dan } \\
\text { menyajikan } \\
\text { hasil kerja ( } 50 \\
\text { menit) }\end{array}$ & $\begin{array}{l}\text { - Dosen meminta beberapa orang mahasiswa } \\
\text { untuk mempresentasikan hasil kerjanya di depan } \\
\text { kelas } \\
\text { - Dosen meminta tanggapan dari mahasiswa lain } \\
\text { terhadap hasil kerja teman yang sudah } \\
\text { dipresentasikan dan mempersilahkan mahasiswa } \\
\text { untuk memberikan alternatif penyelesaian } \\
\text { masalah yang lain. }\end{array}$ & $\begin{array}{l}\text { - } \text { Mahasiswa } \\
\text { mempresentasikan hasil } \\
\text { kerjanya. } \\
\text { - Mahasiswa menanggapi } \\
\text { hasil kerja temannya } \\
\text { dan memberikan alter- } \\
\text { natif penyelesaian ma- } \\
\text { salah yang lain serta } \\
\text { memberika alasan setiap } \\
\text { langkah yang diguna- } \\
\text { kan. }\end{array}$ \\
\hline $\begin{array}{l}\text { Penutup (20 } \\
\text { menit) } \\
\text { 5. Menganalisis } \\
\text { dan mengeva- } \\
\text { luasi proses } \\
\text { pemecahan } \\
\text { masalah }\end{array}$ & $\begin{array}{l}\text { - Dosen memastikan apakah semua mahasiswa } \\
\text { sudah memahami jawaban sebenarnya dari } \\
\text { persoalan yang diberikan, dengan cara bertanya } \\
\text { kepada beberapa orang mahasiswa } \\
\text { - Dosen meminta mahasiswa membuat catatan } \\
\text { harian pada penilaian diri mengenai penjelasan } \\
\text { apa yang ia rasakan setelah mengikuti } \\
\text { perkuliahan, materi-materi yang sudah dan yang } \\
\text { belum ia pahami, dan bagian mana yang dirasa } \\
\text { sulit. } \\
\text { - Dosen meminta mahasiswa membuat } \\
\text { kesimpulan tentang materi yang sudah mereka } \\
\text { pelajari sendiri. } \\
\text { - Dosen memberikan tugas rumah }\end{array}$ & $\begin{array}{l}\text { - } \begin{array}{l}\text { Menjawab pertanyaan } \\
\text { dosen }\end{array} \\
\text { - Mahasiswa membuat } \\
\text { penilaian diri }\end{array}$ \\
\hline
\end{tabular}

8. Penilaian: berisi teknik penilaian dan instrumen penilaian yang digunakan untuk mengukur ketercapaian indikator. Pada RPP yang dikembangkan, penilaian akan dilakukan terhadap buku kerja, penilaian diri, dan tugas rumah.

Isi penilaian diri yang dirancang mengacu kepada metakognisi. Penilaian diri yang telah dirancang terdiri atas 3 aspek, yaitu kemampuan mahasiswa dalam menilai penguasaan pengetahuan, kemampuan mahasiswa dalam menilai pelaksanaan perkuliahan dan kemampuan mahasiswa dalam menilai penguasaan keterampilan. Berikut uraian masingmasing aspek yang dinilai.
1. Kemampuan mahasiswa dalam menilai penguasaan pengetahuan

Hal ini bertujuan untuk menilai sejauh mana penguasaan materi oleh mahasiswa. Bentuk pertanyaan yang diajukan seperti: materi yang dianggap mudah dalam pertemuan ini, materi yang dianggap sulit dalam pertemuan ini.

2. Kemampuan mahasiswa dalam menilai pelaksanaan perkuliahan

Hal ini bertujuan untuk mengetahui pelaksanaan perkuliahan, apakah sudah sesuai dengan harapan mahasiswa atau belum, apakah dapat membantu mahasiswa mengontrol pikirannya. Bentuk pertanyaan yang diajukan 
seperti: cara perkuliahan yang diinginkan dalam mempelajari materi ini.

3. Kemampuan mahasiswa dalam menilai penguasaan keterampilan

Hal ini bertujuan untuk mengetahui keterampilan yang telah dikuasai mahasiswa setelah proses pembelajaran. Bentuk pertanyaan yang diajukan seperti: keterampilan yang diperoleh setelah mempelajari materi ini.
Prototipe RPP dan penilaian diri berbasis metakognisi divalidasi oleh 3 orang pakar yaitu Prof. Dr. I Made Arnawa, M.Si., Dr. Armiati, M.Pd., dan Drs. Syafriandi, M.Si. Hasil validasi RPP (Tabel 4) menggambarkan bahwa komponen RPP dan kegiatan pembelajaran yang tercakup dalam RPP sudah valid. Data hasil validasi penilaian diri (Tabel 5) menunjukkan bahwa penilaian diri yang digunakan juga sudah valid.

Tabel 4. Data Hasil Validasi RPP

\begin{tabular}{clcccccc}
\hline \multirow{2}{*}{ No } & \multirow{2}{*}{ Aspek yang dinilai } & \multicolumn{3}{c}{ Validator } & \multirow{2}{*}{ Jumlah } & \multirow{2}{*}{ K } & \multirow{2}{*}{ Kesimpulan } \\
\cline { 3 - 7 } & & $\mathbf{1}$ & $\mathbf{2}$ & $\mathbf{3}$ & & & \\
\hline 1 & Komponen RPP & 26 & 24 & 27 & 77 & 73,3 & Valid \\
\hline 2 & Kegiatan Pembelajaran & 38 & 35 & 38 & 111 & 82,2 & Sangat valid \\
\hline \multicolumn{2}{c}{ Jumlah keseluruhan } & & & 188 & 78,3 & Valid \\
\hline
\end{tabular}

Tabel 5. Data Hasil Validasi Penilaian Diri

\begin{tabular}{cllllllll}
\hline No & \multicolumn{1}{c}{ Aspek yang dinilai } & \multicolumn{3}{c}{ Validator } & Jumlah & \% & Kesimpulan \\
\cline { 3 - 6 } 1 & $\begin{array}{l}\text { Pernyataan sesuai dengan } \\
\text { indicator }\end{array}$ & 4 & 4 & 4 & 12 & 80 & Valid \\
\hline 2 & $\begin{array}{l}\text { Kalimat yang digunakan } \\
\text { sesuai dengan kaidah Bahasa } \\
\text { Indonesia }\end{array}$ & 4 & 4 & 4 & 12 & 80 & Valid \\
\hline 3 & $\begin{array}{l}\text { Kalimat yang digunakan } \\
\text { komunikatif }\end{array}$ & 4 & 3 & 4 & 11 & 73.3 & Valid \\
\hline 4 & $\begin{array}{l}\text { Pernyataan yang digunakan } \\
\text { tidak bias }\end{array}$ & 3 & 4 & 4 & 11 & 73.3 & Valid \\
\hline \multicolumn{1}{c}{ Jumlah keseluruhan } \\
\hline
\end{tabular}

Secara umum, pakar menyarankan perbaikan RPP pada Standar Kompetensi, materi dan penulisan rumus. Standar Kompetensi sebaiknya dipecah menjadi statistika deskriptif, peluang dan statistika inferensial. Adanya penambahan materi ukuran letak dari sekumpulan data, diagram histogram dan ogive, hukum peluang, peluang bersyarat dan aturan Bayes. Sedangkan perbaikan untuk penilaian diri dilakukan pada kriteria penilaian diri dan perbandingan persentase nilai akhir dari nilai mahasiswa dan dosen. Selanjutnya RPP dan penilaian diri berbasis metakognisi diperbaiki sesuai saran dan komentar validator.

\section{PEMBAHASAN}

Hasil validasi terhadap RPP menunjukkan bahwa validator menyatakan bahwa standar kompetensi harus meliputi semua topik pada matakuliah Statistika Elementer, yaitu statistika deskriptif, peluang, dan statistika inferensial. Peneliti memperbaiki perumusan standar kompetensi sesuai dengan saran validator tersebut. RPP sudah memuat komponen-komponen RPP menurut Permen 41 tahun 2007. Penjabaran Kompetensi dasar ke dalam indikator kompetensi sudah tepat. Indikator yang baik mempunyai ciri-ciri sebagai berikut; memuat kemampuan dasar yang diukur, memeuat kata kerja operasional yang dapat diukur, berkaitan dengan 
materi pembelajaran, dapat dibuat dalam bentuk soal tertentu (Rozi, 2007: 71). Kegiatan pembelajaran yang dirancang pada RPP sudah sesuai dengan konsep metakognisi. Hal ini terlihat dari modelmodel pembelajaran yang digunakan dapat berasosiasi dengan pendekatan metakognisi.

Penilaian diri untuk matakuliah Statistika Elementer sudah valid berdasarkan hasil penilaian validator. Namun, validator menyarankan adanya petunjuk pada penskoran penilaian diri. Hal ini bertujuan untuk membantu dosen dalam memberikan skor. Hal ini sesuai dengan pendapat Puskur (2006: 39) tentang penilaian diri dilakukan berdasarkan kriteria yang jelas dan objektif.

\section{PENUTUP}

Setelah melalui suatu prosedur yang refleksif, yang dimulai dari analisis kebutuhan dan perancangan prototipe, penelitian ini telah menghasilkan prototipe RPP dan penilaian diri berbasis metakognisi untuk mata kuliah Statistika

\section{DAFTAR RUJUKAN}

Afriyani, Dona. 2010. Penelusuran Perilaku Metakognitif Mahasiswa Tadris Matematika dalam Pemecahan Masalah Matematika. Tesis tidak diterbitkan. Padang: Pascasarjana UNP.

Akker, Jan Van Den dan Plomp, Tjeerd. 1994. Educational Development in Developing Countries. Dalam Skutsch, Margaret M., Opdam, J. Hans M. and Nordholt, Nico G. Schulte (Eds.), Towards Sustainable Development. Enschede: Technology and Development Group University of Twente.

Biryukov, P. 2004. Metacognitive Aspects of Solving Combinatorics Problems. International Journal for Mathematics Teaching and Learning (Online), Vol 1 (74)
Elementer. Hasil validasi oleh pakar pendidikan matematika dan pakar statistika menunjukkan bahwa prototipe RPP dan penilaian diri berbasis metakognisi yang dikembangkan memenuhi kriteria valid dari segi isi (content validity) dan konstruksi (construct validity) setelah dilakukan beberapa revisi.

Penelitian ini dapat dijadikan pedoman bagi penelitian selanjutnya, karena penelitian ini masih pada tahap validasi RPP dan penilaian diri berbasis metakognisi. Peneliti lain dapat menelitinya untuk tahap praktikalitas dan tahap efektifitas.

Penelitian ini hanya merancang RPP dan penilaian diri berbasis metakognisi untuk mata kuliah Statistika Elementer. Karena dosen juga sangat membutuhkan RPP dan penilaian diri berbasis metakognisi, maka disarankan kepada peneliti lain untuk dapat mengembangkan RPP dan penilaian diri berbasis metakognisi untuk mata kuliah yang lain.

ISSN 1473-0121, (http://www.ex.ac.uk/cimt/ijmt/bir yukov.pdf diakses 2 Juni 2009).

Blakey, E \& Spence, S. 1990. Developing Metacognitive. Eric Degests on Information Resources (Online). (http://www.iap.ac.id/ ERICDigests/metacognitive.html, diakses 17 Juli 2009).

Fitriza, Rozi. 2007. "Pengembangan Perangkat Penilaian Berbasis Kelas Untuk Pembelajaran Matematika Di Kelas VII SMPN 7 Padang". Tesis tidak diterbitkan. Padang: Pascasarjana UNP.

Huitt, B. 1997. Educational Psychology Interactive: Metacognition (Online). (http://chiron.valdosta.edu/ whuitt/Col/Cogsys/Metacogn.html diakses 17 Juli 2009). 
NCTM. 1999. Curriculum and Evaluation Standards for School Mathematics. Reston, VA: NCTM.

Prajitno, Edi. 2003. Pengembangan Sistem Penilaian. Materi Diklat Kerjasama FMIPA UNY dengan Direktorat PLP Depdiknas. Yogyakarta, 4-14 Juni.

Indeks

belajar...... 168, 170, 171, 174, 175, 176

mahasiswa... 1, 168, 169, 170, 171, 172, $174,175,176,177,178,179$

masalah 1, 168, 169, 170, 171, 172, 174, $175,176,177$

metakognisi. 1, 168, 169, 170, 171, 172,
Pusat Kurikulum Balitbang. 2006. Model Penilaian Kelas. Jakarta: Depdiknas.

Ronis, Diane. 2001. Problem Based Learning for Math and Science: Integrating Inquiry and the Internet. America: Skylight Training and Publishing Inc.

Uno, Hamzah B. 2008. Model Pembelajaran. Jakarta: Bumi Aksara.

pembelajaran 1, 168, 169, 170, 173, 174, 175,179

pendidikan $168,174,175,179$

pengembangan 1,173 penilaian...... 1, 169, 173, 174, 175, 177, 178,179 